\title{
First report of genus Chroococcidiopsis (cyanobacteria) from Sri Lanka: a potential threat to human health
}

\author{
D.N. Magana-Arachchi* and R.P. Wanigatunge \\ Institute of Fundamental Studies, Hantana Road, Kandy.
}

Revised: 24 October 2012 ; Accepted: 19 November 2012

Keywords: Chroococcidiopsis, cyanobacteria, 16S rRNA gene.

Cyanobacteria (Cyanophytes, Cyanoprokaryotes) are a large group of photosynthetic bacteria and one of the most fascinating groups of organisms on the earth. They show a considerable morphological diversity. Microscopy is the classical method of cyanobacterial identification and community assessment. It is difficult to classify cyanobacteria into accurate taxonomic groups since cyanobacterial morphology varies significantly in response to fluctuations of environmental conditions. Consequently, molecular biological techniques have become a popular tool for phylogenetic analysis of the cyanobacteria. Among the various gene sequences used to assess cyanobacterial biodiversity, 16S rRNA gene has been applied more frequently because it is ubiquitous, function is conserved, the gene is easy to sequence and a large database is available for sequence alignments and identification (Kumari et al, 2009).

A number of studies have been conducted in Sri Lanka for identifying fresh water cyanobacteria based on morphological features, and about 170 cyanobacterial species belonging to 45 genera have been described (Abeywickrama et al., 1986). Microcystis aeruginosa, M. flos-aquaeM, incerta, M. wesenbergi, Cylindrospermopsis, Aphanizomenon, Spirulina, Anabaena aphanizomenoids, Anabaena flos-aquae, Aphanocapsa, Chroococcus, Gloeocapsa, Nostoc and Coelosphaerium have been frequently recorded from different parts of the country. However, there are no recorded reports on Chroococcidiopsis species from Sri Lanka.
Members of the genus Chroococcidiopsis are very primitive, photosynthetic, coccoid cyanobacteria and they have the capability to survive under high radiation, extreme temperatures, osmotic stress and extreme $\mathrm{pH}$ values. Genus Chroococcidiopsis have been found in freshwater, marine, hypersaline environments (Dor et al., 1991), hot springs, nitrate caves (Geitler, 1933; Friedmann, 1962), hot and cold deserts, airspaces of porous rocks from Antarctic valleys and in several lichens as cyanobionts (Büdel et al., 2000).

While investigating the biodiversity of cyanobacteria in different parts of Sri Lanka, Chroococcidiopsis species were identified from the Yala National Park, Hambantota, Sammanthurai, the Kondawatuwana Tank and the Mahaweli River using molecular techniques. It is interesting to note that until now there have been no reports indicating the occurrence of Chroococcidiopsis species in Sri Lanka.

Water and soil samples were collected into sterilized brown glass containers from Yala, Hambantota, Sammanthurai, the Kondawatuwana Tank and the Mahaweli River (Table 1). Collected water samples were concentrated by centrifugation (3500 rpm, $10 \mathrm{~min}$ ). An aliquot of $500 \mu \mathrm{L}$ from the centrifuged pellet and $500 \mu \mathrm{L}$ from the supernatant and soil samples were inoculated into cyano specific media. Morphological observations were made from each sample using compound light microscope (Olympus BH2) $(400-1,000 \times)$ and standard identification keys for cyanobacteria. Cultures were incubated at $28 \pm 2{ }^{\circ} \mathrm{C}$ and under fluorescent light with a 12:12-h D/L cycle. An aliquot of $500 \mu \mathrm{L}$ of the cultured sample from each site along with $500 \mu \mathrm{L}$ of standard

\footnotetext{
"Corresponding author (nayomam@yahoo.com)
} 
M. aeruginosa culture [obtained from the Pasteur Culture Collection (PCC 7941), France] were subjected to DNA extraction according to the Boom's method (Boom et al., 1990) using silica particles and guanidium isothiocyanate. DNA amplification was performed for the 16S rRNA gene to identify the presence of cyanobacteria with the modified protocol of Nübelet al. (1997) using the cyanobacteria-specific primers, forward primer CYA359F (5'-GGGGAATYTTCCGCAATGGG-3') and the reverse primer CYA781Rb (5'-GACTA CAGGGGTATCTAATCCCTTT-3'). All PCR reactions were performed in a $50 \mu \mathrm{L}$ reaction mixture containing $0.6 \mu \mathrm{M}$ of each primer, $100 \mu \mathrm{M}$ of each deoxynucleoside triphosphate, $10 \mu \mathrm{L}$ of $5 \mathrm{x}$ PCR buffer, $2 \mathrm{mM} \mathrm{MgCl}_{2}, 2.5 \mathrm{U}$ of Taq DNA polymerase (Promega, Madison, Wisconsin, USA) and template DNA. Thermal cycling was performed in a Techine TC 3000 DNA Thermal Cycler. The initial denaturation step at $94{ }^{\circ} \mathrm{C}$ for $5 \mathrm{~min}$ was followed by 35 cycles of denaturation at $94{ }^{\circ} \mathrm{C}$ for $1 \mathrm{~min}$, annealing at $60{ }^{\circ} \mathrm{C}$ for $1 \mathrm{~min}$, extension at $72{ }^{\circ} \mathrm{C}$ for $1 \mathrm{~min}$ and a fiinal extension step at $72{ }^{\circ} \mathrm{C}$ for $15 \mathrm{~min}$. Aliquots of the resulted amplified products were electrophoresed in 1.5 $\%$ agarose gels containing $10 \mu \mathrm{gmL}^{-1}$ ethidium bromide and documented through a Gel Documentation System (Syngene, UK). PCR products were carefully excised and purified with the GenElute ${ }^{\mathrm{TM}}$ Gel Extraction Kit (SIGMA) according to the manufacturer's instructions and DNA sequencing was carried out by Macrogen Inc., South Korea using ABI 3730XL sequencers with the corresponding reverse primer. DNA sequences obtained in this study were deposited in GenBank under accession numbers EU276382, EU276383, EU310420, EU310430, EU310432, GU300772 and GU594024.

Microscopic observation of wet mounts of cultures identified the unicellular nature of the cyanobacteria. The mature undivided cells were spherical, dark blue green in colour. They formed round or quadratic shaped colonies. There were no considerable morphological variations among the colonies (Figure 1). According to the gel profiles obtained, all DNA samples submitted to PCR reactions with cyanobacterial specific oligonucleotide primers yielded the unique fragment of $\sim 450 \mathrm{bp} .16 \mathrm{~S}$ rRNA sequences of the tested isolates showed a DNA sequence similarity of 96 to $99 \%$ with previously reported Chroococcidiopsis isolates (Table 1).

The occurrence of Chroococcidiopsis species in Hambantota, Ampara as well as in the Mahaweli River (Kandy) shows the diverse geographical distribution of the species in Sri Lanka. This new occurrence may indicate the selection of clones adapted to present environmental conditions or a large physiological tolerance to environmental parameters in this species. Further, ecophysiological experiments are needed to unravel this problem. According to a study by Bahl et al. (2011), massively parallel pyrosequencing of environmental samples collected from all continents

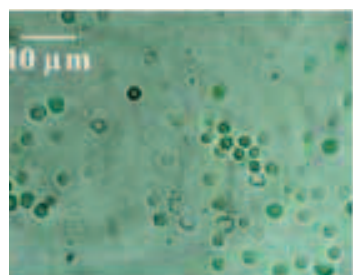

L5

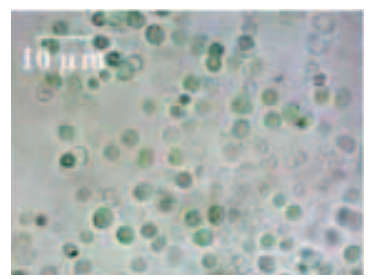

Batti6.2

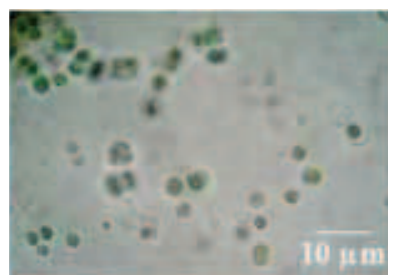

$1 \mathrm{R}$

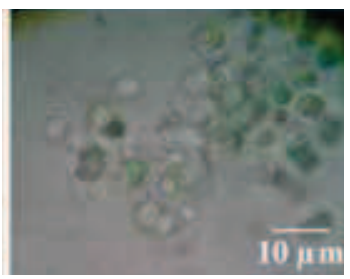

AP2

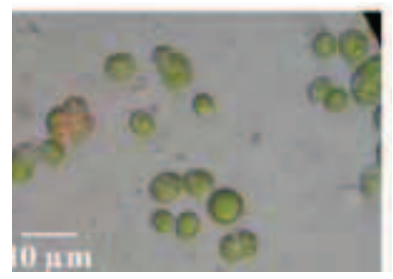

D3

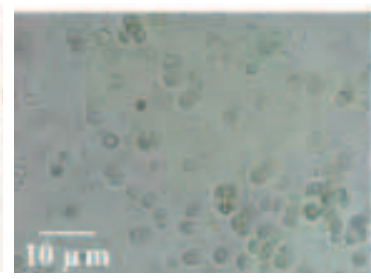

YRS4a

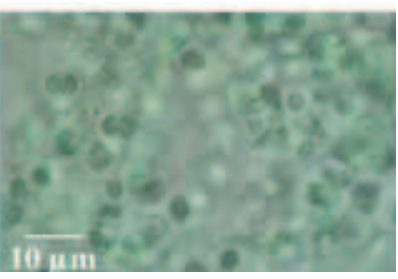

M3

Figure 1: Light microscopic view of Chroococcidiopsis isolates identified from five locations of Sri Lanka (magnification x1000) 
Table1: Details of the sample collection of local isolates of Chroococcidiopsis sp. and comparison of 16S rRNA sequences

\begin{tabular}{|c|c|c|c|c|c|c|}
\hline $\begin{array}{l}\text { Sample } \\
\text { Code }\end{array}$ & Location & $\begin{array}{l}\text { Location } \\
\text { co-ordinates }\end{array}$ & $\begin{array}{l}\text { Source of } \\
\text { isolation }\end{array}$ & $\begin{array}{l}\text { Accession } \\
\text { number }\end{array}$ & $\begin{array}{l}\text { Highest match with } \\
\text { NCBI database }\end{array}$ & $\%$ similarity \\
\hline YRS4a & Yala National Park & $6.16 \mathrm{~N}, 81.15 \mathrm{E}$ & $\begin{array}{l}\text { Crust from } \\
\text { beach rock }\end{array}$ & EU310420 & $\begin{array}{l}\text { Chroococcidiopsis sp. } \\
\text { SAG } 2025 \text { (AM709635) }\end{array}$ & 97 \\
\hline D3 & Hambanthota & $6.11 \mathrm{~N}, 81.11 \mathrm{E}$ & Soil (Nonagama) & EU310430 & $\begin{array}{l}\text { Chroococcidiopsis thermalis } \\
\text { CCALA } 048 \text { (HM630155) }\end{array}$ & 97 \\
\hline L5 & Sammanthurai area & $7.36 \mathrm{~N}, 81.80 \mathrm{E}$ & $\begin{array}{l}\text { House hold well } \\
\text { water mixed with } \\
\text { tsunami waves }\end{array}$ & EU276383 & $\begin{array}{l}\text { Uncultured } \\
\text { Chroococcidiopsis sp. clone } \\
\text { 1P-2-N12 (EU705152) }\end{array}$ & 99 \\
\hline $1 \mathrm{R}$ & Sammanthurai area & $7.36 \mathrm{~N}, 81.80 \mathrm{E}$ & $\begin{array}{l}\text { House hold well } \\
\text { water mixed with } \\
\text { tsunami waves }\end{array}$ & EU276382 & $\begin{array}{l}\text { Uncultured } \\
\text { Chroococcidiopsis sp. clone } \\
\text { 1P-2-N12 (EU705152) }\end{array}$ & 99 \\
\hline Batti6.2 & Sammanthurai area & $7.36 \mathrm{~N}, 81.80 \mathrm{E}$ & $\begin{array}{l}\text { House hold well } \\
\text { water mixed with } \\
\text { tsunami waves }\end{array}$ & EU310432 & $\begin{array}{l}\text { Chroococcidiopsis thermalis } \\
\text { PCC } 7203 \text { (FJ805841) }\end{array}$ & 98 \\
\hline AP2 & Kondawatuwana tank & $7.28 \mathrm{~N}, 81.64 \mathrm{E}$ & Water & GU300772 & $\begin{array}{l}\text { Uncultured } \\
\text { Chroococcidiopsis sp. clone } \\
\text { 1P-2-N12 (EU705152) }\end{array}$ & 99 \\
\hline M3 & Mahaweli River & $8.46 \mathrm{~N}, 81.23 \mathrm{E}$ & Water & GU594024 & $\begin{array}{l}\text { Uncultured } \\
\text { Chroococcidiopsis sp. clone } \\
\text { 1P-2-N12 (EU705152) }\end{array}$ & 96 \\
\hline
\end{tabular}

confirmed that Chroococcidiopsis variants were specific to either hot or cold deserts and the distribution was dependent on contemporary climate. The global distribution for Chroococcidiopsis has been limited by barriers to long distance dispersal and/or invasive colonization, with regional gene pools maintained over geological timescales. Environmental selection may also have exerted a major role in colony establishment in different geographical regions (Bahl et al., 2011).

Finally, as Chroococcidiopsis species are known to produce $\beta-\mathrm{N}$-methylamino-L-alanine, a neurotoxic amino acid (Cox et al., 2004) and hepatotoxic microcystin, the toxicity of Chroococcidiopsis species should be determined. Furthermore, the risk of contamination of water used for drinking purposes by Chroococcidiopsis species should be assessed in order to prevent the risk to human health.

\section{REFERENCES}

1. Abeywickrama B.A., Abeywickrama L., Arulgnanam P. Jansen M.A.B. (1986). The Genera of the Freshwater Algae of Sri Lanka - Part II. Natural Resources, Energy \& Science Authority of Sri Lanka, Maitland Place, Colombo 07.

2. Bahl J., Lau M.C.Y., Smith G.J.D., Vijaykrishna D., Cary S.C., Lacap D.C., Lee C.K., Papke R.T., Warren-Rhodes K.A., Wong F.K.Y., McKay C.P. \& Pointing S.B. (2011). Ancient origins determine global biogeography of hot and cold desert cyanobacteria. Nature Communications 2(163),DOI: 10.1038/ncomms116.

3. Boom R., Sol C.J.A., Salimans M.M.M., Jansen C.L., Wertheim-Van Dillen P.M.E. \& Noordaa J.V.D. (1990). Rapid and simple method for purification of nucleic acids. Journal of Clinical Microbiology 28(3): 495 - 503.

4. Büdel B., Becker U., Follmann G. \& Sterflinger K. (2000). Algae, fungi and lichens on inselbergs. Inselbergs (eds. S. 
Porembski \& W. Barthlott), pp. 69 - 90. Springer-Verlag, Heidelberg, Germany.

5. Cox P.A., Banack S.A., Murch S.J., Rasmussen U., Tien G., Bidigare R.R., Metcalf J.S., Morrison L.F., Codd G.A. \& Bergman B. (2004). Diverse taxa of cyanobacteria $\beta$ -N-methylamino-L-alanine, a neurotoxic amino acid. Proceedings of the National Academy of Science 102(14): $5074-5078$.

6. Dor I., Carl N. \& Baldinger I. (1991). Polymorphism and salinity tolerance as a criterion for differentiation of three new species of Chroococcidiopsis (Chroococcales). Algological Studies 64: $411-421$.

7. Friedmann E.I. (1962). The ecology of the atomphytic nitrate alga Chroococcidiopsis kashaii Friedmann: studies on cave algae from Israel. IV. Archiv für Mikrobiol 42: $42-45$.

8. Geitler L. (1933). Diagnosen neuer Blaualgen von den Sunda-Inseln. Archiv fuer Hydrobiologie: supplement band 8: 622 .

9. Kumari N., Srivastava A.K., Bhargava P. \& Rai L.C. (2009). Molecular approaches towards assessment of cyanobacterial biodiversity. African Journal of Biotechnology 8(18): $4284-4298$.

10. Nübel U., Garcia-Pichel F. \& Muyzer G. (1997). PCR primers to amplify $16 \mathrm{~S}$ rRNA genes from cyanobacteria. Applied and Environmental Microbiology 63: 3327 - 3332. 